\title{
The Analysis of Conditions and Level of Sustainable Development of Rural Areas in Poland And Germany
}

By

\author{
Aleksandra JEZIERSKA-THOLE ${ }^{1}$ and Miroslaw BICZKOWSKI ${ }^{1}$
}

\begin{abstract}
The aim of this article is to present the conditions for sustainable development of rural areas in Poland and Germany. The paper attempts to determine the appropriate system of indicators and measures in four dimensions: environmental, economic, spatial and social, that can be used to evaluate sustainable development. The comparative analysis of the sustainability level was based on the correlation analysis. . The high level of sustainable development was observed in rural areas of the zone of direct impact of larger urban agglomerations. The further from the centre of the city, the lower level of development was recorded. The counties showing small differences between the three dimensions (environmental, social and economic) have a higher level of sustainable development. Those showing large differences between the three dimensions have a lower level of balance between the natural, social and economic dimensions.
\end{abstract}

Key Words: sustainable development, rural development measures, Poland, Germany

\section{Introduction}

The concept of sustainable socio-economic development has become the response of the international community to the perceived threats resulting from excessive anthropopressure on the natural environment. Sustainable socio-economic development is one of the most important challenges of the modern world. This development relates to the environmental, economic and social aspects. The need for introducing restrictions to economic changes so as they did not affect the environment, was expressed by economist, Nobel laureate J. Stiglitz (2004, p 142), who said that the "existence of future generations cannot happen at the expense of the present generations", as well as by D. Jeffrey, who said that the "self-regulating forces of the market economy should be guided by the overarching principles of social justice and regulations for the protection of the environment" (Sachs, 2007). Similarly, Z. Sadowski (2005) believes that the economic development should contribute to improving the fate and living conditions of the entire human population, and not just some of it. A condition for sustainable development is the ability to cross the limits to growth and development of the community, i.e. to prepare in advance the educational and scientifictechnical development conditions for crossing these limits to growth (Michnowski, 2003).

It should be emphasised that sustainable development of rural areas should adapt to local natural conditions as well as opportunities and social and economic needs of the 
region. In practice, this means that it is not always and everywhere possible to introduce the concept of development, i.e. we need to exclude the forested areas, water bodies as well as protected and culturally valuable areas. The aim of the study was therefore to present conditions for sustainable development in rural areas and to compare the spatial diversity of the sustainable development level in North and West Poland and East Germany. The study attempts to assess sustainable development with the use of the selected measures and indicators.

\section{Materials and Methods}

In the specialist literature, there are two perception areas of the concept of sustainable development. The first one concerns ecology, while the second one focuses on the economic and social issues. Proponents of the first approach identify sustainable development with the environmental development, harmonised with the natural environment. The authors of the second approach take into account a need to meet three objectives: economic, social and environmental (Baker, 1999, Daub, 2006).

The concept of sustainable development is to create a state of balance in rural areas, both in the economic and social sphere as well as in terms of the natural environmental sphere, and stems from the adoption of rule of integrated governance. According to K. Malik (2012) a developed form of integrated governance is a complex of five dimensions: socio-institutional, political, economic, environmental and spatial. Socio-institutional governance refers to the society living with the sense of integration and social cohesion, and is formed as a result of economies of scale and a system of values. Environmental governance defines the use of natural resources and environmental services in a way that does not affect the balance of the ecological chain but which maintains the productivity of ecosystems (Boris, 2010). The way in which elements of the integrated governance are correlated is based on three main governance types (social, economic and environmental) and two specific types of governance (institutional and spatial). The interrelation of types of governance enables the realisation of the concept of sustainable development.

The sustainable development model developed by M. Adamowicz and A. Smarzewska (2009) was based on a set of categories of developmental characteristics and refers to the terms 'durability' and 'sustainability'. The model is based on two characteristics of durability: sensitive and strong. In the model of sustainable development the integrated governance moves in the space between the plane with the "limited substitution of capital" (reflecting the sensitive principle of durability) and the plane called the "complementarity of capital" (reflecting the strong principle of durability). The sensitive principle of durability means the limited substitution of anthropogenic and environmental capital; this principle is based on the prudent use of natural resources (Sand, 2007). The principle of durability takes into account the complementarity of capital, while it excludes their substitutability (fig. 1).

In this study it was assumed that sustainable development consists of a broad group of interdependent but equal ecological, social, economic and political objectives. The ecological objectives include environmental protection and preservation of nonrenewable resources. The economic objectives are focused on sustainable economic development using the latest environmentally-friendly production methods, less and less polluting the environment. The social objectives mean providing equal opportunities for 
development and access to the use of the environment for present and future generations.

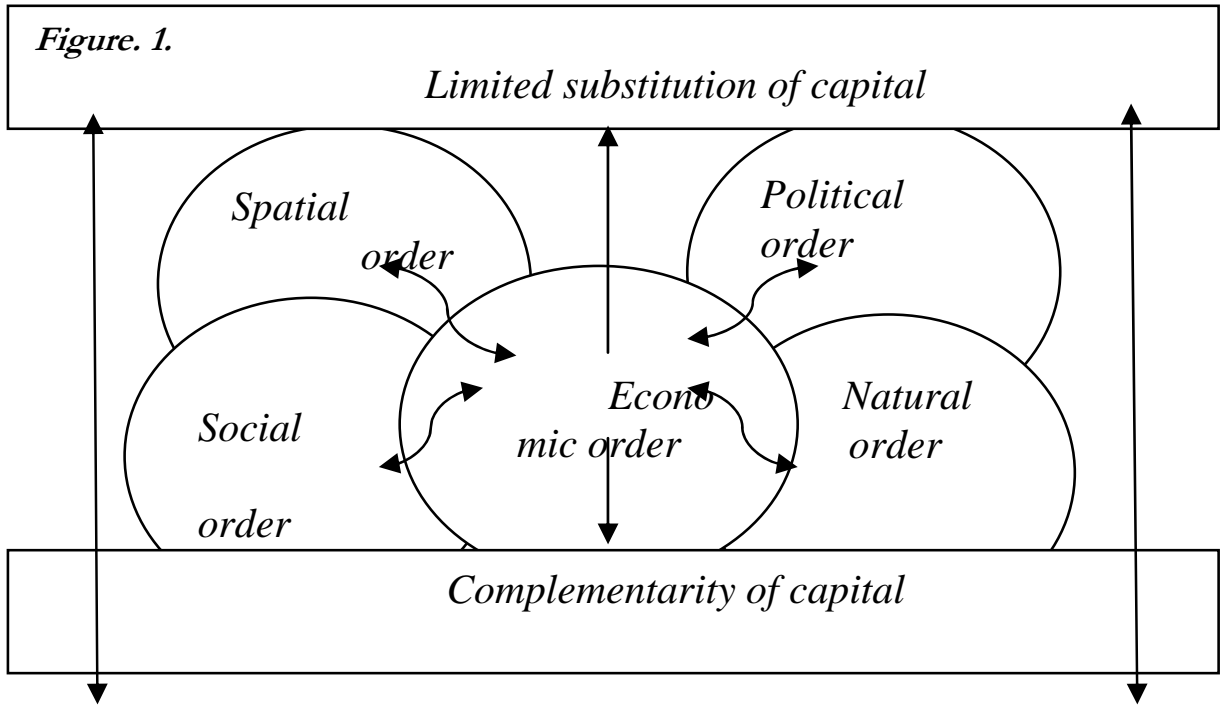

Source: own compilation on: M. Adamowicz i A. Smarzewska (2009).

The study area were rural areas of eight Polish districts (voivodeships): WarmińskoMazurskie, Kujawsko-Pomorskie, Pomorskie, Zachodniopomorskie, Wielkopolskie in North Poland and Lubuskie, Opolskie and Dolnośląskie in West Poland, as well as five federal states (Länder) in East Germany: Mecklenburg-Vorpommern, Brandenburg, Saxony-Anhalt, Saxony and Thuringia. In total, Polish 152 counties and 64 German counties were analysed. Choosing East Germany for a comparative study stemmed from a common political and economic past and history. Poland and eastern Länder of Germany belonged to the block of "eastern countries" pursuing - in various manners the socialist model of the economy. Similarly, in the areas of North Poland the economic policy of the Duchy of Prussia was implemented, which contributed to, for instance, the emergence of large-scale farms. The time scope of work included the year 2010. The study was based on the statistical data of the Central Statistical Office of Poland and the Federal Statistical Office of Germany.

The paper attempts to determine the appropriate system of indicators and measures by which it is possible to assess the level of sustainable development (Table 1). The selected indicators come from a "long list" of sustainable development indicators (Borys, 2005, Adamowicz, 2005). Sets of indicators are created to control the recommendations of the Global Programme of Action (Agenda 21) and are used for the diagnosis and management of areas in environmental, social and economic spheres. The EU system of sustainable development indicators consists of ten thematic areas: socio-economic development, sustainable production and consumption, social inclusion, demographic changes, public health, climate change as well as energy, sustainable transportation, natural resources, global partnership and good governance (Sustainable 2009). 
Table 1. The list of indicators of the natural, economic, spatial and social assessing the degree of sustainable development

\begin{tabular}{|c|c|c|}
\hline \multicolumn{2}{|c|}{ Indicators assessing the natural order and spatial Field } & Domain \\
\hline $\mathrm{X}_{1}$ & Share of forest land in the total area $(\%)$ & \multirow[t]{4}{*}{ Protection of nature } \\
\hline $\mathrm{X}_{2}$ & Share of protected areas in the total area $(\%)$ & \\
\hline $\mathrm{X}_{3}$ & Population using water $(\%)$ & \\
\hline $\mathrm{X}_{4}$ & Opulation using the sewage system (\%) & \\
\hline \multicolumn{3}{|c|}{ Assessing the economic order } \\
\hline $\mathrm{X}_{5}$ & Share of employment in services (\%) & Employment \\
\hline $\mathrm{X}_{6}$ & Income of district from the share in tax revenue - $\mathrm{zl}$ per inhabitant & Municipal budget \\
\hline $\mathrm{X}_{7}$ & Expenditure budget of the municipality for one inhabitant ( zł ) & \multirow[t]{2}{*}{ Entrepreneurship } \\
\hline $\mathrm{X} 8$ & $\begin{array}{l}\text { Entrepreneurship - measured as the number of economic entities per } 10000 \\
\text { inhabitants at working age }\end{array}$ & \\
\hline $\mathrm{X}_{9}$ & Length of water mains per $\mathrm{km}^{2}$ & \multirow{3}{*}{$\begin{array}{l}\text { Technical } \\
\text { infrastructure }\end{array}$} \\
\hline $\mathrm{X}_{10}$ & Length of sewerage network per $\mathrm{km}^{2}$ & \\
\hline $\mathrm{X}_{11}$ & Gas network length per $\mathrm{km}^{2}$ & \\
\hline $\mathrm{X}_{12}$ & Share of agricultural land in the total area $(\%)$ & \multirow[t]{2}{*}{ Agriculture } \\
\hline $\mathrm{X}_{13}$ & Share of arable land in the area of agricultural land $(\%)$ & \\
\hline \multicolumn{3}{|c|}{ Indicators assessing the social order } \\
\hline $\mathrm{X}_{14}$ & Economic burden rate & \multirow[t]{3}{*}{ Demography } \\
\hline $\mathrm{X}_{15}$ & Ratio of natural increase (\%o) & \\
\hline $\mathrm{X}_{16}$ & Natural increase & \\
\hline $\mathrm{X}_{17}$ & Expenditure as a share of the municipal budget on education (\% ) education & \multirow[t]{2}{*}{ Education } \\
\hline $\mathrm{X}_{18}$ & Number of children in kindergartens for 100 children & \\
\hline $\mathrm{X}_{19}$ & Employment rate ( the number of employees per 1,000 inhabitants), & \multirow{2}{*}{$\begin{array}{l}\text { The economic } \\
\text { activity residents }\end{array}$} \\
\hline $\mathrm{X}_{20}$ & Participation in the number of working -age population (\%) & \\
\hline $\mathrm{X}_{21}$ & Unemployment in the population of working age in as a percentage $(\%)$ & \multirow{2}{*}{$\begin{array}{l}\text { Poverty and } \\
\text { social exclusion }\end{array}$} \\
\hline $\mathrm{X}_{22}$ & Municipal budget expenditure on social protection per 1 inhabitant (zł) & \\
\hline $\mathrm{X}_{23}$ & Municipal budget expenditure on education per 1 inhabitant $(\mathrm{zl})$ & \multirow[t]{6}{*}{ Standard of living } \\
\hline $\mathrm{X}_{24}$ & Municipal budget expenditure on health care per 1000 inhabitants ( zł ) & \\
\hline $\mathrm{X}_{25}$ & Expenditure of the municipal budget for culture and sport per 1000 inhabitants & \\
\hline $\mathrm{X}_{26}$ & Expenditure of the municipal budget for cultural centers per 1 inhabitant $(\mathrm{zl})$ & \\
\hline $\mathrm{X}_{27}$ & Expenditure of the municipal budget for culture and art on one inhabitant ( $\mathrm{zl}$ ) & \\
\hline $\mathrm{X}_{28}$ & GDP per capita 1 & \\
\hline
\end{tabular}

Source: Borys (2005), Adamowicz. (2004), Sustainable... (2009), Jezierska-Thole, Kluba (2012)

\section{Results and Discussion}

Determinants of sustainable development in rural areas are shown on the example of the selected indicators by which the level of sustainable development was assessed. Among the indicators of social governance the chosen measure was unemployment rate, which indicates economic activity of the region and the supply of jobs. A high value of the indicator of registered unemployed may indicate low economic activity of the inhabitants. In 2010, an average of $9.8 \%$ of the economically active population was unemployed in North and West Poland and 11.4\% in East Germany. The highest unemployment rate was recorded in Mecklenburg in the County of Demmin $(17.4 \%)$. High unemployment rates of above $15 \%$ were recorded in four regions: the Counties of Lipno and Pisz (17.0 and 16.2\%, respectively), followed by the Counties of 
Bartoszyce (16.7\%), Uckermark (16.3\%) and Włocławek (15.2\%). In contrast, the lowest unemployment rates are recorded in rural areas of the Wielkopolskie Voivodeship in which the lowest value was recorded in the County of Poznań (2.4\%). Low unemployment rate is a characteristic of rural areas in the vicinity of urban agglomerations: Wrocław, i.e. the County of Wrocław (3.6\%), Tri-City (Gdańsk - Gdynia - Sopot), i.e. the County of Gdańsk (3.9\%) and Toruń and Bydgoszcz. In rural areas of East Germany a relatively low unemployment rate is recorded by counties adjacent to the metropolis of Berlin (fig. 2).

Figure. 2. Participation of the unemployment in the population in of working age as a percentage (\%)

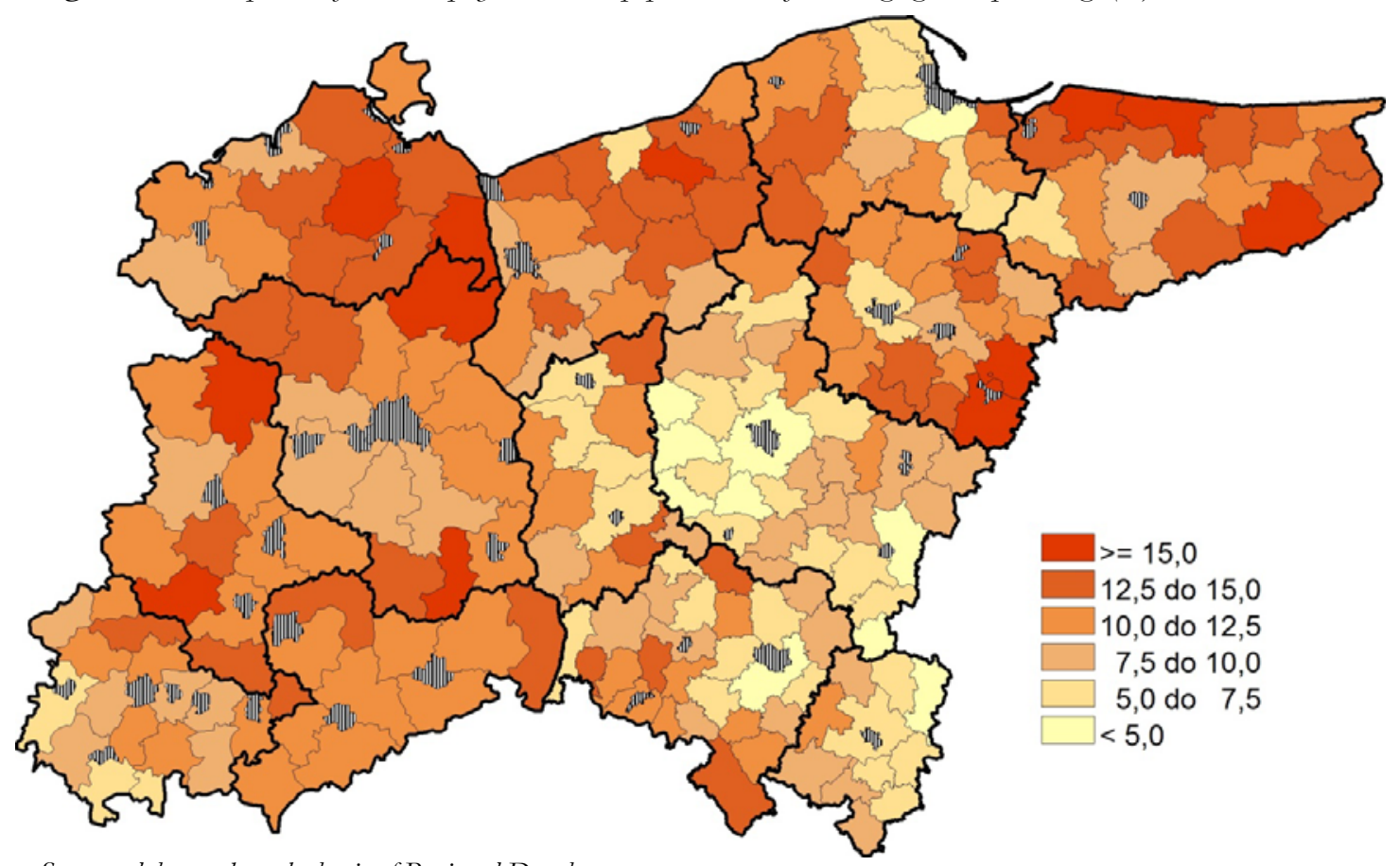

Source: elaborated on the basis of Regional Database

Another measure - the number of economic entities per 10000 inhabitants - is a simplified measure of entrepreneurship of the municipality's residents. In 2010, the average rate of entrepreneurship for the North and West Poland was 891, which was two times higher than this rate for East Germany (423). Spatial analysis of the indicator shows that the largest number of economic entities is registered in the coastal counties, i.e. in the Counties of Kołobrzeg (1707 - maximum value), Koszalin, Sławno and Lębork, and in those located around the voivodeship capitals, such as the Counties of Poznań, Gryfice and Stargard. Despite the large entrepreneurship in rural areas in Poland, the income of municipalities is very low compared to rural areas in East Germany. This situation shows large disparities of development (fig. 3).

The large differences in the measures of local sustainable development of the counties, referring to the social, economic and environmental spheres, evidence of a low balance level between these spheres. 
Figure. 3. Entrepreneurship - measured as the number of economic entities per 10000 inhabitants

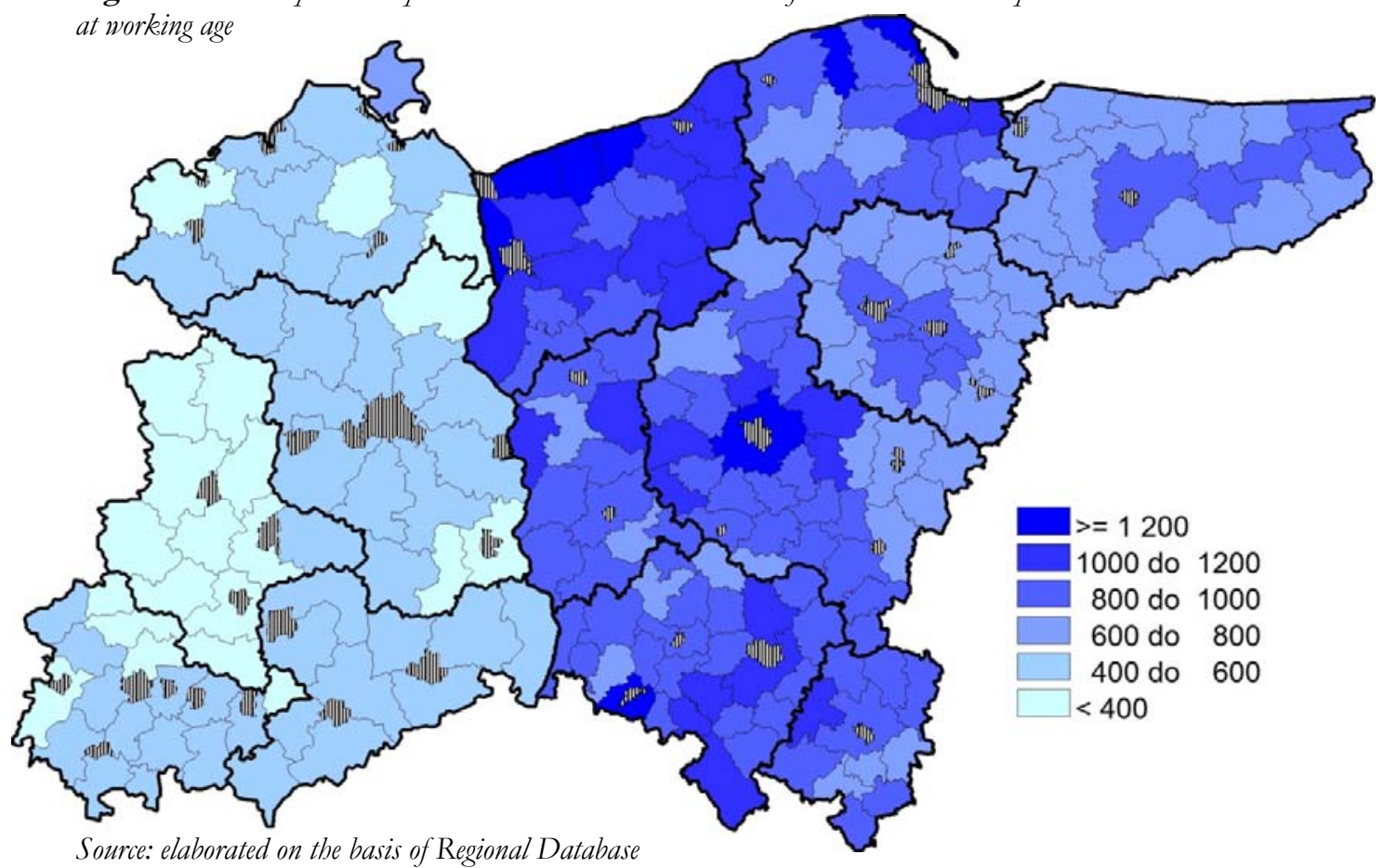

The indicators selected to determine the sustainability level allow obtaining statistical data on the county level. The evaluation of development based on the Perkal (1964) synthetic index (Jezierska-Thole 2013) allowed dividing the test area into four main groups in terms of sustainable development (table 2).

Table 2. Level of Carpathian communes economic development in 2010

\begin{tabular}{|l|l|l|l|}
\hline Group & Level of economic development & Number of commune & $\%$ \\
\hline 1 & Very hight & 35 & 16.2 \\
\hline 2 & Higt & 81 & 37.5 \\
\hline 3 & Low & 71 & 32.9 \\
\hline 4 & Very low & 29 & 13.4 \\
\hline
\end{tabular}

Source: elaborated on the basis of GUS Regional Database

The results indicate that the level of sustainable development is strongly spatially diverse (fig. 4). A very high level was reached by 35 counties, which accounted for $16.2 \%$ of the total. Comparative analysis of the level of sustainable development of rural areas of Poland and Germany shows that in East Germany the counties with a high level of development are concentrated in Brandenburg, while in Poland they are found in all the analysed voivodeships except for the Warmińsko-Mazurskie Voivodeship. The highest level of economic development is characteristic for the rural areas located directly on the Baltic Sea and around major conurbations.5). The highest level was reached by the Counties of Kołobrzeg (0.66) followed by the Counties of Poznań (0.64), Puck (0.57), Gdańsk (0.55) and Dahme-Spreewald (0.51). 
Figure 4. Level of commune sustainable development

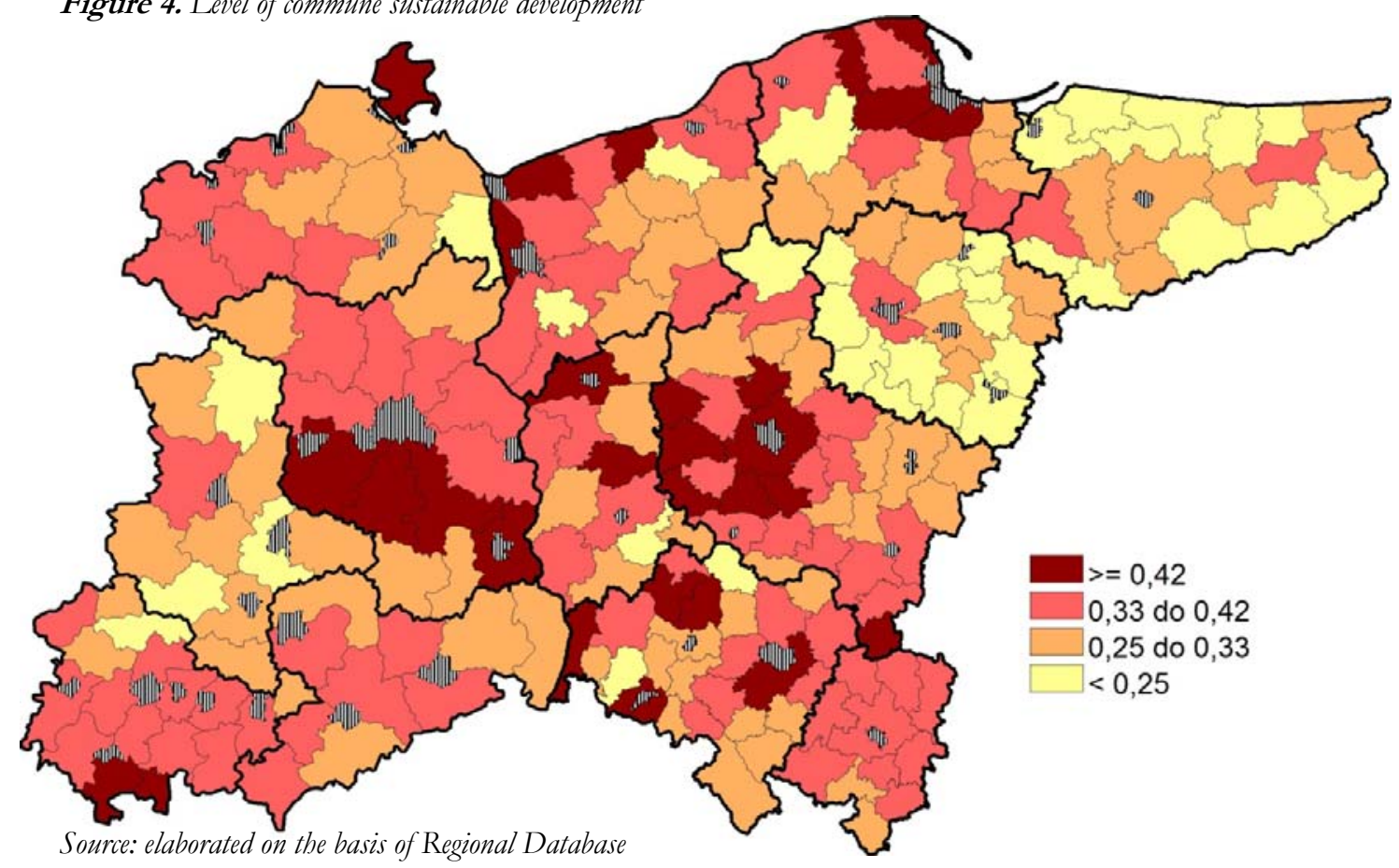

The rural areas with the lowest level of sustainable development are situated in the Warmińsko-Mazurskie Voivodeship. The County of Bartoszyce recorded the minimum value (0.13). Low levels occurred in the Counties of Lipno and Pisz ( 0.15 each) as well as Grudziądz and Włocławek (0.16 each). Numerous studies of the authors of the article (Jezierska-Thöle, 2012, Gwiaździńska, 2004) clearly indicate that the delay in the economic development of poviats in the Kujawsko-Pomorskie Voivodeship is related to the agrarian overpopulation and lack of income opportunities in non-agricultural activities. Underdevelopment of the poviats of the Warmińsko-Mazurskie Voivodeship, however, is related to the dominance of large-scale farms and limited labour market.

\section{Conclusions}

The challenge of the modern world is sustainable development, which stems from the adoption of the integrated governance and aims to create a state of balance in the economic, social and environmental spheres. Based on the analysis of the specialist literature two approaches to sustainable development were highlighted. The first one focuses on the natural environment, while the second one on the economic and social issues. In this study it was assumed that the sustainability consists of a broad group of interdependent and equal objectives of ecological, social and economic character.

Assessment of the level of sustainable development of rural areas was based on the appropriately selected indicators in four dimensions: environmental, economic, spatial and social. The examined rural areas showed different levels of sustainability, expressed by affiliation to a specific level of development. The adopted levels of sustainable development were as follows: below average, relatively moderate and above average. The 
high level of sustainable development was observed in rural areas of the zone of direct impact of larger urban agglomerations. The further from the centre of the city, the lower level of development was recorded. The counties showing small differences between the three dimensions (environmental, social and economic) have a higher level of sustainable development. Those showing large differences between the three dimensions have a lower level of balance between the natural, social and economic dimensions.

Comparative analysis of the level of sustainable development of rural areas of Poland and Germany indicates that in East Germany the counties with a high level of development are found in Brandenburg; in Poland, however, they are found in all the analysed regions except for the Warmińsko-Mazurskie Voivodeship.

\section{References}

Adamowicz M. (2005) Sustainable and multifunctional development of agriculture and agronomy, Uniwerytet Marii Curie Skłodowskiej, , S Sect. E 60, , Lublin, Poland, p. 71-91 (in Polish).

Adamowicz M., Smarzewska A. (2009) Model and measures for sustainable development of rural areas. p. 251-268. (12.02.2014, in Polish).

Agenda 21 in Poland. 10 years after Rio 1992-2002, (2002) Raport. Narodowy Fundusz Ochrony Środowiska. Warszawa, Poland , p. 10-12. (in Polish).

Baker S. (2003) The Dynamics of European Union Biodiversity Policy: Interactive Functional and Institutional Logics, Environmental Politics 123 (2003), p. 24-41 (in English).

Borys T. (2005)_Sustainable development indicators, Ekonomia i Środowisko, Białystok. (in Polish).

Borys T. (2010) Decade of Education for Sustainable Development - Challenges Polish, Problems of Sustainable Development, 5, 1. (in English).

Daub C-H. (2006) Globale Wirtschaft - globale Verantwortung: Die Integration multinationaler Konzerne in den Prozess der nachhaltigen Entwicklung (Global Economy - Global Responsibility: The integration of multinational corporations in the process of sustainable development) ed. gesowip, Basel, p.34-42. (in German).

Jezierska-Thöle A., Kluba M. (2012) Einfluss der Mitgliedschaft Polens in der Europäischen Union auf die demographischen Veränderungen in der polnischen Landwirtschaft (Influence of Poland's membership in the European Union due to demographic changes in Polish agriculture), In: Transformation in Deutschland und Polen Europäische Regionen im Wandel, Demokratieentwicklung in Polen und in den neuen Bundesländern, Europäische Akademie Berlin, Osteuropa Zentrum Verlag, Berlin, p.132-135 (in German).

Jezierska-Thöle, A., Gwiaździńska-Goraj, M., 2013, Assessment of the level of economic development of rural areas of Northern Poland. Rural Development 2013: Vol. 6/1, p. 548-552(in English)

Malik K. (2012) The Effectiveness and Efficiency of Regional Development Policy, [w:] G. Hofbauer, H. Haensel (red.), Challenges, Research and Perspectives - Herausforderungen, Forschung und Perspektiven. European Research and Working Group. Berlin: uni-edition GmbH, Berlin, s. 287300. (in English).

Michnowski L. (2003) Analysis of variability in shaping the sustainable development strategy, In: A. Pawłowski (ed.), Filozoficzne i społeczne uwarunkowania zrównoważonego rozwoju, Monografie Komitetu Inżynierii Środowiska Polskiej Akademii Nauk, 16, Lublin, p.45. (in Polish).

Sachs J. (2007) Common challenges, common good, Uniwersytet Ekonomiczny, Kraków, Poland, p.12. (in Polish).

Sadowski Z. (2005) Transformation and development, PTE, Warszawa, Poland, p.69-72. (in Polish).

Sand, P. (2007) Sustainable Development - of Forests, Ships, and Law. Some Historical Annotations. Environmental Policy and Law 37/2-3, p. 77. (in English).

Stiglitz, E. (2004) Globalization, Polskie Wydawnictwo Naukowe, Warszawa, Poland, p. 142-143. (in Polish).

Sustainable development in the European Union - 2009 monitoring report of the EU sustainable development strategy. European Commission, p.145-165 (in polish).

Sustainable Territorial Development of the Rural Areas of Europe, (2004), The Agriblue Blueprnt, Europen Commission, 16-20 (in English). 